\title{
Minutes of March 2018, APSA Council Meeting
}

\author{
Saturday, March 3, 2018 \\ Washington, DC \\ The DuPont Circle Hotel
}

\section{MEMBERS PRESENT \\ President: Kathleen Thelen; Past President: David Lake; President- Elect: Rogers Smith; Vice President: Evelyne Huber; Vice President: Gary Segura; and Treasurer: Thomas Pepinsky \\ Council Members: Matt Barreto, Joseph Carens, Mark Crescenzi, Omar Encarnación, Lisa Garcia-Bedolla, Kristian Gleditsch, Lilly J. Goren, Simon Jackman, Amaney Jamal, Matthew Kocher, Brett Ashley Leeds, James Mahoney, Byron D’Andra Orey, Erin Richards, Colleen Shogan, Valeria Sinclair-Chapman, Laura Sjoberg, Cameron Thies, Caroline Tolbert, Renée Van Vechten, Carol Weissert, and Christina Wolbrecht Guests: Robert Liberman \\ APSA Staff: Steven Rathgeb Smith, Betsy Super, Kara Abramson, Dan Gibson, Kimberley Mealy, Jon Gurstelle, Megan Davis, Tanya Schwarz, Meghan McConaughey, and Teka Miller \\ Not in Attendance: Juliet Hooker, Pippa Norris, Bo Rothstein}

\section{CALL TO ORDER}

APSA President Kathleen Thelen called the meeting to order on March 3, 2018 at 8:30am.

\section{CONSENT AGENDA}

Thelen introduces the 2018 record dates for Council approval. Jamal moves to approve record dates for 2018. The motion is seconded and approved unanimously.

\section{TREASURER'S REPORT}

Treasurer Thomas Pepinsky introduces the treasurer's report to update the Council on the association's financial position. Pepinsky reports that APSA continues in sound financial shape. The 2017 independent audit was conducted by the auditing firm Rubino \& Company. At November 30, 2017, the total fair market value of all APSA investments was $\$ 37.6$ million, with the most significant investment groups being the Trust and Development portfolio which totaled $\$ 16.6$ million and the Congressional Fellowship Program trust portfolio which total $\$ 17.5$ million.

Jamal asks if, due to the stability and growth of APSA's endowment, there are plans to spend down some of the money, or if the association plans to allow the endowment to accumulate. Executive Director Steven Smith and Past President David Lake note that APSA budgets a yearly percentage draw from the endowment and that in 2017 the Council's executive committee decided that any budget surplus will be spent rather than rolling the surplus back into the endowment. As per a previous (Fall 2017) Council decision, the budget surplus for 2017 will be spent through a special project fund. Smith adds that the Council has created an Investment Committee, which plans to review APSA investment policy and come to the fall Council meeting with recommendations. Carens asks if APSA does any ethical screening of investments. S. Smith replies that this is part of the review the Investment Committee is undertaking. Encarnación asks about the potential for future surpluses and Van Vechten asked if APSA has determined an ideal endowment level and the potential that it may make sense to spend down some of the endowment. Thelen notes that this has been considered and the current approach is to maintain the current level of the endowment and to spend any surplus on programming that will benefit the whole association.

\section{PRESIDENT'S REPORT}

Thelen reports on recent association activities and accomplishments to update the Council on the state of the association. Thelen discusses the new Investment Committee; data collection efforts in APSA journals; and pipeline issues including the Project on Women and Minorities survey. She also updates the Council on the accelerated approval of meeting notes and the recently launched Special Projects Fund.

\section{APSR EDITOR SEARCH}

Thelen introduces discussion of the APSR editor search as part of the President's report, for the purpose of updating Council. As background, she notes that the current Mannheim team has indicated that it will not extend its term beyond June 2020. APSA plans to issue the call for proposals for a new editor(s) on an accelerated timeline beginning in the spring, in order to ensure that we have sufficient time to solicit and vet proposals and finalize a contract in time to facilitate a smooth transition. To increase the pool of institutions that can submit proposals, APSA is actively exploring options for the association (headquarters) to take over some of the editorial functions, which would allow a wider range of institutions (including less well resourced ones) to apply. S. Smith notes there are various editorial models that may help address the issue of whether institutions have the capacity to host the APSR.

Segura and Lake discuss the resource burden on institutions editing APSR and note that both in terms of resources and capacity this model does not seem to be sustainable. Sjoberg notes that, on the other hand, she would be hesitant to send the journal to an institution that was not willing to make financial commitment to it. APSA President-Elect Rogers Smith indicates that he is heartened that the editor search is starting early, and that APSA is open to a variety of applications. He also mentions that the exclusivity and high demand for publication in APSR creates an editorial and administrative burden, as it receives a very high number of submissions.

Van Vechten agrees and suggests that because so few submissions are published APSR should consider publishing more frequently. Segura adds that the number of submissions to APSR has increased while the journal has maintained the same output. Shogan notes that political scientists are writing in a variety of formats, and political science journals should consider this if they want to have a more practical impact. Sinclair-Chapman suggests that the call for editors should make clear that APSA is open to creative and new types of editorial models. Thelen agrees and adds that cost sharing is an option. Thelen goes over the timeline of the editor search and closes the conversation.

\section{EXECUTIVE DIRECTOR'S REPORT}

S. Smith introduces discussion of ongoing and new APSA programing to provide 
updates to the Council. S. Smith discusses a project increasing eJobs transparency by allowing departments to provide updates on the status of searches through eJobs. Wolbrecht asks how APSA plans to incentivize departments to update eJobs, and S. Smith replies that APSA plans to work with department chairs. S. Smith updates the Council on teaching and learning efforts, including the Teaching and Learning Conference at the APSA Annual Meeting, teaching workshops at APSA headquarters, pedagogy workshop at the Annual meeting, syllabi collection, enhanced resources on the APSA website, and possible partnership with the Political Studies Association for a TLC conference in the UK in 2019. Richards asks if teaching and learning workshops can be posted online to allow faculty without resources to attend to benefit from these programs. S. Smith replies that he is supportive of that and will follow up. Tolbert, Van Vechten, and Richards discuss the importance of online teaching resources, including for getting community colleges involved with APSA, and S. Smith agrees and notes that there are proposals and efforts along those lines. In particular, providing helpful topical teaching resources that can be used in the classroom as well as engaging with primarily teaching faculty to create videos and resources addressing common teaching and classroom management strategies could be a good way to better serve teaching faculty. As APSA further considers the importance of primarily teaching faculty in the association and tries to more fully incorporate both teaching and research faculty this may be one good approach. S. Smith provides additional updates on Middle East and North Africa (MENA) workshops, an APSA-sponsored Methodology Workshop at the Mexican Political Science Association (AMECIP) annual conference in August 2018, and discussions with Pi Sigma Alpha on APSA becoming their fiscal sponsor.

\section{SEXUAL HARASSMENT POLICY}

Thelen introduces an amendment to the sexual harassment policy for council discussion and approval. This amendment addresses concerns raised by the Ethics Committee, which has recommended suspending the current sexual harassment policy while the deficits are addressed. Thelen, R. Smith and Lake were concerned that suspending the policy would send the wrong signal at a critical moment in the important debates that have been unfolding within our association. As an alternative, they propose amending the policy to address the concerns the committee raised regarding the composition of the committee that deals with harassment complaints. The proposed amendment was distributed to the Council. Super projects the proposed changes and sends a track changes version of the amendment to the Council. Thelen opens the amendment to discussion.

S. Smith provides greater background on the amendment, which proposes the creation of an ad hoc committee to address sexual harassment complaints. S. Smith explains that the current policy calls for complaints to be lodged with a subset of the ethics committee, but the ethics committee feels as though they are not the proper body to address these complaints. Under the proposed amendment, the expectation is that the Executive Director would have a list of eight to twelve people with an appropriate background that could serve on an ad hoc committee that would investigate if a sexual harassment complaint were made at APSA annual meeting, the Teaching and Learning Conference, or an APSA workshop. Shogan asks what an appropriate background would be. S. Smith suggests that people with institutional experience dealing with similar issues would be ideal, but people with appropriate training might also serve.

Garcia-Bedolla suggests that in the future APSA might consider using a third-party option to investigate and evaluate complaints. Other associations use this approach, and she thinks this is a good alternative, as it advantages speed and expertise, and reduces the chance of conflicts of interest. Sjoberg agrees that using a third party to evaluate complaints helps avoid the appearance of bias. Goren expresses agreement and also notes that it is important to have on-site procedures clearly understood and communicated. Sinclair-Chapman notes that while she is not opposed to using a third-party to investigate complaints she agrees with the amendment as proposed for an immediate solution.

Lake notes that the amendment allows for the in-take advisor to start to gather information at the meeting, and in the case of egregious behavior the Executive Director may sanction a member in consultation with the intake advisor and APSA president. Shogan, Leeds and Segura ask about when it is appropriate for the intake officer or APSA representatives to contact law enforcement, and whether staff, Council members and officers are required to report harassment. Thelen and R. Smith note that physical danger would merit a law enforcement response but, while the ombuds would inform complainants of their options, the complainant should choose to contact law enforcement and APSA should not make that choice for them. Garcia-Bedolla agrees that good systems are victim-led. Lake notes that APSA needs to consider what to do if APSA staff and officers know of an incident but the victim is unwilling to file a formal complaint. S. Smith reports that APSA has consulted with legal counsel and confirmed that APSA staff and Council members do not have legal obligations to report complaints of sexual harassment.

Segura and Sinclair-Chapman discuss how the policy will be disseminated and how to use this to signal professional boundaries and change the environment in the discipline. Sinclair-Chapman and Leeds agree that, in the long run, APSA may need a policy that covers other types of harassment in addition to sexual harassment. Jamal agrees that ongoing discussion is necessary, including the question of what to do if someone accused of sexual harassment assumes a position of leadership in APSA.

Thelen agrees that this amendment to the policy does not mean the end of discussions on sexual harassment. Kocher asks if APSA has considered a system like Callisto. Thelen replies that Mealy has been looking into it, and Mealy explains that Callisto is an information escrow system that has been used on college campuses, and APSA is investigating whether it could be used for APSA meetings. Thelen adds that one could imagine how this sort of software could work for a consortium of associations and cover multiple political science meetings.

Thelen brings the conversation back to the proposed revised policy as well as the amendments to the proposal, which make additional edits to ensure that the policy is consistent with the proposed change in the constitution of the harassment committee. The proposed revision to the policy, as distributed to Council, replaces section V on the constitution of the harassment committee with language creating an ad hoc committee to investigate and evaluate complaints. The amendment, as distributed, makes an additional change to section $\mathrm{V}$, and edits to VI.C.3 and VII. 11 to maintain consistency. Van Vechten and Lake ask if the policy applies to all APSA events, as the Teaching and Learning Conference is not included in the policy. S. Smith and Thelen agree that this should be amended. Super recommends that the amended language should indicate that the policy applies to all APSA 
conferences, meetings, and workshops. Garcia-Bedolla moves to amend section III to indicate that the sexual harassment policy applies to "APSA conferences, meetings, and workshops." The motion is seconded and passes unanimously. Thelen moves to amend the sexual harassment policy, which will be reflected sections IV,VI.C.3 and VII.11, as distributed to Council. The motion is seconded and passes unanimously.

Thelen invites further input from the ethics committee to address other aspects of the current sexual harassment policy that they found wanting.

\section{ORGANIZED SECTION HANDBOOK}

S. Smith introduces the revised Organized Section Handbook for Council discussion and approval. S. Smith provides background on the revised Organized Section Handbook, which was updated to match policies to practice and to ensure that the Organized Section policies followed the new bylaws. S. Smith notes that one notable change is that to become a section, a section previously needed 200 signatures and then needed 250 members within one year of approval as a section to remain listed. The Membership and Professional Development Policy committee has proposed that this rule be changed to 200 signatures and 200 members within one year.

S. Smith also highlights the issue of what should be done when a section falls below the required 200 members. He explains that no section has ever been decertified because it fell below 200 members, though six sections are currently in the high one hundreds in terms of membership. Encarnación proposes an amendment that any Organized Section that falls below 200 members for three consecutive years will have its status suspended. Its existing members will have the opportunity to transition to another Organized Section or working group, and to reapply for Organized Section status one year after the suspension. APSA will notify all Organized Sections of their status every year.

Sjoberg expresses concern about automatic suspension and suggests that sections below 200 members should be subject to a review, which could consider why small sections can add value to the association. Jamal remarks that incorporating a review raises the issue of subjective evaluation. Lake states that he is in favor of amendment proposed by Encarnación, as a section has to have 200 members to become a section, and the section will have three years of warning after falling below 200 members, which provides an opportunity for sections to increase their membership. Weissert adds that she is in favor of this change, but expresses concern about when membership is measured because it fluctuates over the course of the year. Encarnación answers that measurements should happen right after the Annual Meeting. Carens asks why APSA uses 200 as its threshold for organized section membership, noting that the number seems rather high. Orey and R. Smith note that a higher membership requirement discourages fragmentation, which is a concern. Thelen moves to vote on the amendment to the revised Organized Section Handbook, which would replace section VII with the following language: "Any Organized Section that falls below 200 members for three consecutive years will have its status suspended. Its existing members will have the opportunity to transition to another Organized Section or working group, and reapply for Organized Section status one year after the suspension. APSA will notify all Organized Sections of their status every year." The motion is seconded and passes with a vote of 24 in favor, one against, and one abstention.

Lake proposes an additional amendment, that officers of Organized Sections cannot serve more than two terms in the same position. S. Smith explains that he encourages change of leadership when addressing sections, but finding treasurers for sections is difficult and sections may have trouble with that requirement. Sinclair-Chapman expresses worry over the enforceability of the proposed amendment. Lake notes the importance of this feedback, and suggests that this proposal go to the Membership and Professional Development Committee for further discussion and consideration. Thelen agrees to refer Lake's proposal to the committee.

Thelen moves for a vote on the whole revised Organized Section Handbook. The motion and is seconded and passes with 25 in favor and one abstention.

\section{DIVERSITY AND INCLUSION REPORT}

Mealy introduces discussion of the diversity and inclusion report for the purpose of updating Council. Mealy provides an overview of the data and information included in the report, as well as APSA programs, services, and reports that address issues of diversity and inclusion. Leeds and Sinclair-Chapman express interest in advertising how institutions engage in diversity and inclusion, as a way to share best practices in diversity and inclusion efforts and to put pressure on institutions. Segura expresses that it is important to consider not just 'do APSA programs work,' but also 'what more can APSA do?' Kocher encourages APSA to focus more attention on non-tenure-track faculty, a status that represents a majority of faculty in the profession, and overlaps significantly with other inequalities. To the extent that women and other minorities are underrepresented in the association, some of that could be addressed by focusing more attention on contingent and other non-research faculty. Garcia-Bedolla and Segura discuss the need for additional data, including longitudinal information and comparative data. Thelen agrees and notes that APSA data is also limited to APSA members, which is a limitation her task force is working to address. Sinclair-Chapman notes that APSA needs to incentivize the behavior it wants as well as build on programs that recognize and identify challenges. Mealy thanks the Council for their discussion and suggestions and Thelen notes that APSA will continue to invest in diversity and inclusion efforts.

\section{EXECUTIVE DIRECTOR CONTRACT RENEWAL}

The Council discusses renewal of the Executive Director's contract in executive session.

\section{RBSI STEERING COMMITTEE REPORT}

Mealy introduces discussion of the RBSI Steering Committee Report for the purpose of updating Council. Mealy gives background on the report and states that the RBSI Advisory Committee will be submitting recommendations for the Fall 2018 Council Meeting.

\section{NEW ORGANIZED SECTION PROPOSAL}

S. Smith introduces a proposal for a new organized section, International Collaboration, for Council discussion and approval. S. Smith explains that when a new organized section applies, they have to provide 200 signatures and demonstrate that their existence does not overlap with an existing section. The proposal is considered by the Organized Section Committee then submitted to Council. The proposed International Collaboration Section has the requisite signatures and has been recommended for approval by the Organized Section Committee. Lake adds that International Collaboration has been a longstanding division. S. Smith notes that the panels that come with being a division will transfer to the new organized section. 
Segura moves to approve the proposed Organized Section, the motion is seconded, and passes with 25 in favor and one abstention.

\section{ROGERS SMITH PRESIDENTIAL TASKFORCE UPDATE}

R. Smith introduces discussion of his Presidential Taskforce on New Partnerships to update the Council. Along with the chair of his taskforce, Robert Lieberman, he updates the council on the timeline for the taskforce, its current activities, as well as its desired outputs. R. Smith and Lieberman state that the taskforce is meant to create programmatic outcomes rather than a research report. They provide background on the three subcommittees of the taskforce: civic engagement, teaching and learning, and research.

\section{THELEN PRESIDENTIAL TASKFORCE} UPDATE

Thelen introduces discussion of her Presidential Taskforce on Women's Advancement in the Profession to update the Council. Thelen gives background on current data collection efforts to address pathway issues as well as research on publications. Thelen adds that at the upcoming Annual Meeting there will a diversity and inclusion hackathon spanning three panels slots. Task Force cochair Mala Htun and Task Force member Al Tillery will issue a call for proposals from APSA members and status committees to propose teams. MIT media lab data visualization experts will be on hand to assist teams in creating compelling presentations of diversity-related data.

\section{POLICY COMMITTEE UPDATES}

Thelen invites the Policy Committees to provide updates to the Council. SinclairChapman discusses the work of the Public Engagement Committee, where they are examining how and where public engagement is being acknowledged and rewarded in promotion and tenure decisions. Jamal provides updates on the three issues tasked to the Conferences and Meetings Committee: all-male panels, related groups, and innovation at the annual meeting. Van Vechten delivers updates on the Teaching and Learning
Committee, where they are working with the Political Science Education Organized Section on the Teaching and Learning Conference at the APSA Annual Meeting, as well as implementing a TLC impact survey. Encarnación provides updates on the Membership and Professional Development Committee, which has addressed the organized section issue as well as diversity within APSA. Wolbrecht presents updates on the Publications Committee, where they have worked on gathering data on journal submissions and have discussed new approaches to the APSR editorship.

\section{NEW BUSINESS}

Thelen opens the floor for discussion of new business. Richards expresses discontent that eight of twelve of the nominees for the 2018 2021 Council are from $\mathrm{R} 1$ institutions. Tolbert expresses hope that the association follow up on discussion of an open access journal. Lake reports that in executive session S. Smith's reappointment as APSA Executive Director was approved with an overwhelming majority. 


\section{Iapsa \\ AMERICAN \\ POLITICAL \\ SCIENCE \\ ASSOCIATION}

\section{Join the APSA Experts Database}

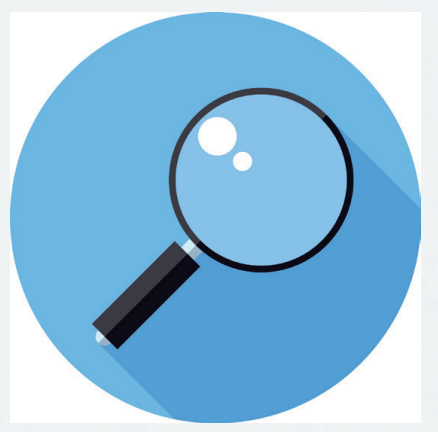

\section{APSA members can sign up to be included in our Experts Database to connect with media requests for professionals in all areas of political science.}

As part of the APSA Public Engagement Program, the experts database promotes dialogue between political scientists and the public to foster better understanding of political science and share insights from the discipline with broad audiences. APSA's public engagement program supports political scientists with resources, training, and opportunities to share their research. APSA highlights members' media interviews, blogs, and op-eds in the weekly press gallery series available on www.politicalsciencenow.com.

\section{Learn more and sign up online at:}

www.apsanet.org/publicengagement

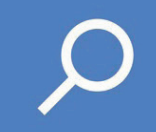

